\title{
ANALISIS PERSEPSI PELANGGAN TERHADAP KUALITAS LAYANAN COFFEE SHOP ASING DAN COFFEE SHOP LOKAL
}

\author{
Marcus Remiasa \\ Dosen Program Manajemen Perhotelan, Fakultas Ekonomi, Universitas Kristen Petra \\ markus@peter.petra.ac.id \\ Yenny Lukman \\ Alumnus Program Manajemen Perhotelan, Fakultas Ekonomi, Universitas Kristen Petra
}

\begin{abstract}
Abstrak: Penelitian ini menganalisis kualitas layanan yang dibagi menjadi tiga jenis kualitas yaitu kualitas interaksi, kualitas lingkungan fisik, dan kualitas hasil di coffee shop asing dan coffee shop lokal berdasarkan persepsi pelanggan, lalu melihat perbedaan di antara keduanya. Hasil yang didapat adalah terdapat perbedaan rata-rata yang signifikan antara coffee shop asing dan coffee shop lokal, di mana coffee shop asing dipersepsikan memiliki kualitas layanan yang lebih baik daripada coffee shop lokal.
\end{abstract}

Kata kunci: Persepsi kualitas layanan, persepsi pelanggan, coffee shop

\begin{abstract}
This research aims to analyze service quality which are classified into three types of quality: interaction quality, physical environment quality, and outcome quality in the foreign coffee shop and the local coffee shop based on the customer perception. Moreover, the writer would like to analyze the Mean differences between foreign coffee shop and local coffee shop. Result shows that service quality of the foreign coffee shop is better than the local one.
\end{abstract}

Keywords: Perceived service quality, customer perception, coffee shop

Sebagai kota metropolitan, Surabaya menjadi pusat kegiatan perekonomian di daerah Jawa Timur dan sekitarnya. Sebagian besar penduduknya bergerak dalam bidang layanan, industri, dan perdagangan. Dewasa ini terdapat 25 mall yang tersebar di 13 kecamatan, dengan jumlah terbanyak di pusat kota (Belajar Melihat Potensi Wilayah dengan GIS, 2007). Pusat perbelanjaan modern ternama diantaranya: Tunjungan Plaza, Pakuwon Trade Center dan Supermall Pakuwon Indah, Golden City Mall, ITC, Bubutan Junction, Royal Plaza, Mal Galaxy, Plaza Marina, dan Plasa Surabaya. (Kota Surabaya, 2007).

Perkembangan kota Surabaya menjadi kota Metropolitan tersebut tidak terlepas dari pengaruh aspek budaya dan sosial yang datang dari luar negeri membuat pola perilaku mayarakat Surabaya berubah. Dengan adanya perubahan dan pengaruh itu, maka menyebabkan pergeseran dan atau perubahan fungsi sebuah kafe atau coffee shop, yang melahirkan fenomena sosial dan budaya baru (Royan, 2004). Di samping sebagai tempat untuk minum teh atau kopi dan menyantap makanan ringan, coffee shop juga sebagai tempat untuk berkumpul, bersosialisasi, berkencan, bertukar pikiran, memperluas jaringan, dan bahkan menjadi salah satu tempat untuk melakukan prospecting business antar eksekutif ("Minum Kopi Bagian Gaya Hidup") sehingga kebutuhan terhadap coffe shop asing dan coffe shop lokal terus berkembang.
Sekarang ini, coffee shop asing yang sudah masuk ke Surabaya, contohnya adalah Starbucks Coffee, The Coffee Bean and Tea Leaf, DOME. Selain coffee shop asing, di Surabaya juga terdapat coffee shop lokal. Salah satunya adalah Kafe Excelso yang merupakan salah satu jaringan kafe terbesar di Tanah Air. Kafe Excelso memiliki 30-an gerai yang tersebar di berbagai kota. "Kafe Excelso ini murni dikembangkan oleh keluarga Soedomo Margonoto (pemilik Group Kapal Api)," (Sudarmadi, 2007). Selain Kafe Excelso, juga ada Grazia Café yang didirikan oleh grup kapal api sebagai coffee shop lokal. Coffee shop asing maupun lokal yang sudah masuk ke Surabaya tersebut berlokasi di shopping centre. Salah satu contohnya yaitu di Tunjungan Plaza, dimana semua coffee shop asing dan coffee shop lokal berada di dalam satu mall, dengan letak yang berdekatan dan strategis. Oleh karena itu pelanggan dihadapkan beberapa pilihan coffee shop asing maupun lokal dengan dukungan fasilitas lengkap, harga bersaing dan kualitas layanan yang sangat bervariatif dan kompetitif.

Dalam bidang industri Jasa, kualitas layananlah yang memainkan peranan penting dalam memberi nilai tambah terhadap pengalaman layanan secara keseluruhan. Oleh karena itu, coffee shop yang mampu memberi kualitas layanan terbaik akan berkembang dan mampu mempertahankan pelanggannya. "Sejak kualitas superior menjadi salah satu 
faktor penting dalam pengendalian industri layanan, Lee, Barker, \& Kandampully (2003) menyarankan bahwa meningkatkan kualitas layanan diseluruh departemen menjadi yang utama dalam kelangsungan industri" (Pei, Akbar \& David, 2005).

Seorang pelanggan akan mengevaluasi kualitas layanan berdasarkan persepsi mereka. Menurut Brady dan Cronin (2001), "persepsi pelanggan terhadap kualitas layanan ini terdiri dari tiga kualitas yaitu kualitas interaksi, kualitas lingkungan fisik, dan kualitas hasil. Ke-tiga kualitas ini membentuk pada keseluruhan persepsi pelanggan terhadap kualitas layanan. Kualitas layanan ini sengaja dipisah-pisahkan supaya memudahkan pihak manajemen dalam melihat evaluasi pelanggan terhadap masing-masing kualitas.

\section{Rumusan Masalah}

Dari latar belakang yang telah dipaparkan di atas, maka dapat disusun rumusan masalah sebagai berikut:

1. Bagaimanakah persepsi pelanggan terhadap kualitas layanan di coffee shop asing?

2. Bagaimanakah persepsi pelanggan terhadap kualitas layanan di coffee shop lokal?

3. Apakah terdapat perbedaan persepsi pelanggan terhadap kualitas layanan di coffee shop asing dan coffee shop lokal?

\section{Batasan Penelitian}

Yang menjadi batasan penelitian ini adalah coffee shop asing dan coffee shop lokal yang berlokasi di Tunjungan Plasa Surabaya.

\section{TEORI PENUNJANG}

\section{Konsep Layanan}

Layanan adalah setiap kegiatan atau manfaat yang ditawarkan oleh suatu pihak pada pihak lain dan pada dasarnya tidak berwujud, serta tidak menghasilkan kepemilikan sesuatu (Kotler, 1999). Selanjutnya, menurut Kotler, Bowen, Makens (1999, pp.42-44) ada 4 karakteristik layanan yaitu:

1. Tidak berwujud (intangibility)

Tidak seperti barang yang dijual, layanan tidak bisa dilihat, dicicipi, dirasakan, didengar, atau dicium sebelum dibeli. Untuk mengurangi ketidakpastian yang disebabkan oleh service intangibility, pelanggan berusaha untuk mencari bukti yang dapat dilihat atau tangible yang dapat memberikan informasi dan keyakinan mengenai pelayanan tersebut.

2. Tidak dapat dipisahkan (inseparability)

Di sebagian besar bisnis layanan, penjual maupun pembeli harus hadir sehingga transaksi dapat terjadi. Pelanggan menghubungi karyawan merupakan bagian dari produk yang dijual. Service Inseparability juga mengandung arti bahwa pelanggan merupakan bagian dari produk. Seorang manajer harus mampu mengatur pelanggan sehingga seorang pelanggan tidak menciptakan ketidakpuasan terhadap pelanggan lain.

3. Berubah-ubah (variability)

Layanan sifatnya berubah-ubah, artinya layanan tergantung pada siapa yang menyediakan, kapan dan dimana serta bagaimana layanan tersebut disediakan.

4. Tidak tahan lama (perishability)

Layanan tidak dapat disimpan. Sebuah hotel dengan 100 kamar yang hanya menjual 60 kamar tidak dapat menyimpan atau menginventaris 40 kamar yang tidak terjual.

\section{Konsep Kualitas Layanan}

Menurut Parasuraman, Zeithaml \& Berry (1985, p.42) ada tiga hal penting yang harus diperhatikan dalam kualitas layanan, yaitu sebagai berikut:

1. Kualitas layanan sulit dievaluasi oleh pelanggan daripada kualitas barang.

2. Persepsi kualitas layanan dihasilkan dari perbandingan antara kepuasan pelanggan dengan layanan yang diberikan secara nyata.

3. Evaluasi kualitas tidak semata-mata diperoleh dari hasil akhir dari sebuah layanan, tapi juga mengikutsertakan evaluasi dari proses layanan tersebut.

Dalam kualitas layanan ada beberapa dimensi atau atribut yang perlu diperhatikan yaitu (Parasuraman, Berry, \& Zeithaml dalam Tjiptono, 2004, p.70):

1. Bentuk fisik/yang berwujud (tangibles) yaitu kondisi yang ada dalam memberikan pelayanan meliputi kualitas fisik, perlengkapan, pegawai dan sarana komunikasi.

2. Keandalan (reliability) yaitu kemampuan memberikan pelayanan yang dijanjikan dengan segera, akurat dan memuaskan.

3. Daya tanggap (reponsiveness) yaitu keinginan para staf untuk membantu pelanggan dan memberikan pelayanan yang tanggap.

4. Jaminan (assurance) yaitu mencakup pengetahuan, kemampuan, kesopanan, dan sifat yang dapat dipercaya yang memiliki para staf, bebas dari bahaya, resiko dan keragu-raguan.

5. Empati (emphaty), meliputi kemudahan dalam melakukan hubungan, komunikasi yang baik, perhatian pribadi dan memahami kebutuhan para pelanggan. 


\section{Konsep Persepsi}

Menurut Kotler dan Amstrong (1997, p.156) "persepsi didefinisikan sebagai proses yang dilalui orang lain dalam memilih, mengorganisasikan, dan menginterpretasikan informasi guna membentuk gambaran yang berarti mengenai dunia". Dari proses memilih, mengorganisasi, dan menginterpretasikan informasi tersebut, seseorang akan memberi makna atau arti dalam bentuk pendapat tentang obyek benda, orang, dan situasi tertentu. Dengan demikian persepsi pelanggan dapat diartikan sebagai pernyataan pendapat pelanggan tentang suatu obyek benda, orang, dan situasi tertentu.

\section{Konsep Perceived Service Quality}

Konsep ini merupakan bagian persepsi yang menyoroti kualitas layanan secara khusus. Tentunya kualitas berdasarkan persepsi pelanggan. Perceived service quality menurut Zeithaml (2003) merupakan dasar dari terbentuknya sebuah kualitas dan dapat digunakan untuk mengukur kepuasan pelanggan. Pelanggan adalah subyek yang menilai dan mengevaluasi sebuah kualitas layanan yang didasarkan pada:

1. Kualitas interaksi

2. Kualitas lingkungan fisik

3. Kualitas hasil

Berikut ini adalah gambar hubungan antara persepsi pelanggan terhadap kualitas dengan kepuasan pelanggan menurut Zeithaml (2003, p.85)

Adapun gambaran tentang ketiga kualitas layanan di atas (kualitas interaksi, kualitas lingkungan fisik, kualitas hasil) juga dijelaskan oleh Brady dan Cronin (2001) dalam penelitian empiriknya. Dan sasaran dari penelitian itu adalah untuk mengidentifikasi suatu konseptualisasi yang terintegrasi dan yang baru dalam kualitas layanan.

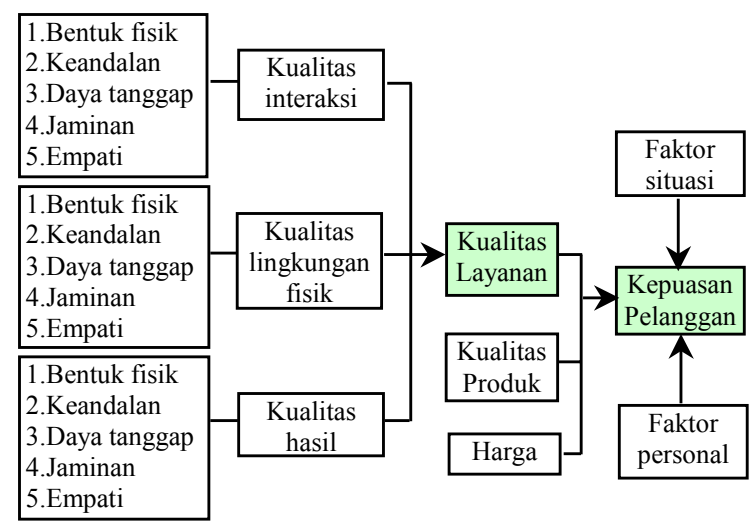

Sumber : Zeithaml (2003, p.85)

\section{Gambar 1. Persepsi Pelanggan terhadap Kualitas dan Kepuasan Pelanggan}

Menurut Brady dan Cronin pelanggan mengevaluasi kualitas layanan didasarkan pada tiga kualitas yaitu kualitas interaksi, kualitas lingkungan fisik, dan kualitas hasil. Dan hasil evaluasi ini yang membentuk sebuah persepsi pelanggan tentang kualitas layanan secara keseluruhan. Gronroos (2000) juga menyebutkan bahwa "pada dasarnya kualitas layanan yang dievaluasi oleh pelanggan memiliki dua dimensi, yaitu a technical quality atau outcome quality dan a functional quality atau interaction quality”. Lalu Rust dan Oliver (Gronroos, 2000) menambahkan physical environment sebagai dimensi lain yang akan dievaluasi oleh pelanggan terhadap kualitas layanan. Atribut-atribut yang ada dalam SERVQUAL sangat penting dalam pembentukan perceived service quality ini. Di dalam model ini keandalan, daya tanggap, dan empati tidak dikenali sebagai penentu langsung dalam kualitas layanan, mereka berperan sebagai atribut yang mendeskripsikan kualitas layanan itu. Sedangkan untuk bentuk nyata bukan sebagai faktor yang mendeskripsikan saja, melainkan sebagai suatu faktor penentu langsung untuk mengevaluasi hasilhasil layanan, sehingga dimasukkan langsung dalam kualitas hasil. Sedangkan atribut jaminan diabaikan karena memiliki beberapa faktor-faktor yang berbeda tergantung pada konteks industrinya (Brady dan Cronin, 2001).

Brady dan Cronin (2001) menggambarkan masing-masing dari tiga kualitas itu dalam tiga subdimensi yang langsung mengukur masingmasing kualitas yaitu:

1. Kualitas interaksi yaitu kualitas yang berhubungan erat dengan bagaimana proses layanan itu disampaikan yaitu dilihat dari proses interaksi staf penyedia layanan terhadap pelanggannya (Gronroos, 2000). Dan proses interaksi tersebut dapat dilihat dari bagaimana cara staf bersikap, berperilaku terhadap pelanggannya serta keahlian yang mereka miliki. Kualitas interaksi digambarkan dalam tiga subdimensi yaitu :

- Sikap yaitu kepribadian yang dimiliki oleh staf yang menunjukkan keramahan terhadap pelanggan. Contohnya, sikap dan kepribadian dari staf di restoran sangat mempengaruhi pendapat pelanggan, staf di sana sangat ramah.

- Perilaku di sini dimaksudkan dengan sifat yang baik dari staf serta kemauan untuk melayani. Contohnya, ketika ada uang pelanggan yang jatuh dari kantong celana dan tidak 
menyadarinya, staf di restoran itu langsung mengejar untuk mengembalikan uang yang terjatuh.

- Keahlian yaitu kemampuan staf dalam melaksanakan pekerjaannya. Contohnya, staf di restoran itu tahu akan pekerjaannya dan memiliki pengetahuan yang bagus serta bisa menjawab pertanyaan yang para pelanggan ajukan dengan cepat.

2. Kualitas lingkungan fisik menurut Rust dan Oliver yaitu sebuah kualitas yang ada di dalam lingkungan di mana proses pelayanan itu terjadi (Gronroos, 2000). Dan kualitas

ini digambarkan dalam tiga subdimensi yaitu:

- Kondisi lingkungan yaitu suatu kondisi yang dapat memberikan kenyamanan yang berkenaan dengan aspek nonvisual. Contohnya, dari jauh, meja di tempat pelanggan duduk terlihat bersih tetapi begitu tangan diletakkan $\mathrm{di}$ atas meja, ternyata permukaan meja itu masih lengket.

- Desain yaitu berhubungan dengan tata letak atau arsitektur ruangan. Contohnya, ketika seorang pelanggan ingin berdiri dari tempat duduk, ternyata kursi tidak bisa didorong mundur karena di belakangnya ada tamu lain yang sedang duduk.

- Faktor sosial yaitu jumlah dan tipe pelanggan lain yang berada dalam lingkungan pelayanan, seperti tentang perilaku mereka. Contohnya, tangisan bayi seorang pelanggan sangat mengganggu pelanggan lain.

3. Kualitas hasil yaitu apa yang pelanggan dapatkan, ketika proses produksi servis dan interaksiinteraksi antara pelanggan dengan penyedia layanan selesai (Gronroos, 2000). Dan kualitas ini digambarkan dalam tiga subdimensi yaitu :

- Waktu tunggu yaitu waktu yang pelanggan gunakan untuk menunggu kualitas yang didapat. Contohnya, untuk memesan 1 gelas es teh manis saja, para pelanggan harus menunggu 30 menit.

- Bentuk nyata yaitu segala sesuatu yang berwujud. Contohnya kualitas hasil yang ada di restoran itu sangat mengesankan, makanan yang ada di sana sangat enak.

- Valensi yaitu ukuran tentang pengalaman yang didapat bisa baik ataupun jelek. Contohnya, ketika meninggalkan restoran itu para pelanggan memiliki pengalaman yang baik karena para staf restoran itu memberikan sesuatu yang berkesan.

\section{Kerangka Pemikiran}

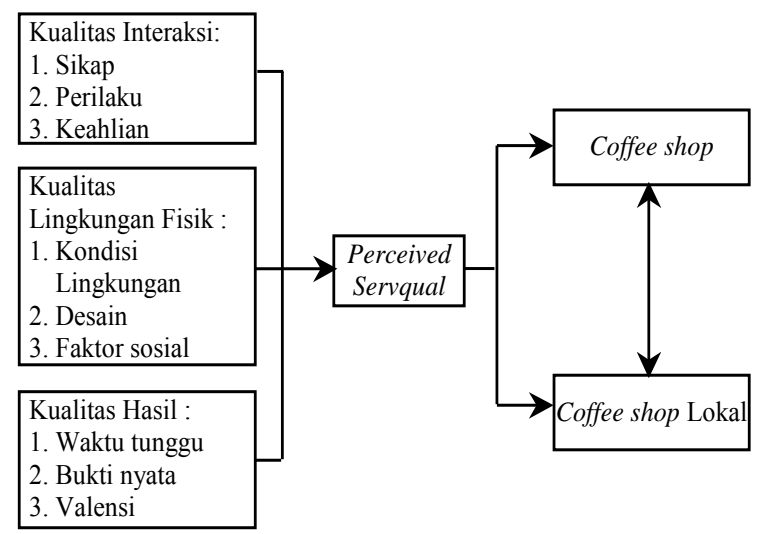

Gambar 2. Kerangka Pemikiran

\section{Hipotesis}

Pada penelitian-penelitian sebelumnya, evaluasi terhadap kualitas layanan biasanya tidak dipisahpisahkan. Hal ini membuat pihak manajemen kesulitan dalam melihat kualitas mana yang membuat pelanggan puas ataupun kecewa. Tetapi penelitian yang dilakukan oleh Brady dan Cronin dapat membantu pihak manajemen dalam mengatasi kesulitan tadi yaitu dengan memisah-misahkan kualitas layanan dalam tiga kualitas yaitu kualitas interaksi, kualitas lingkungan fisik, dan kualitas hasil. Oleh karena itu pada penelitian ini dapat diambil kesimpulan sementara sebagai berikut:

1. Terdapat perbedaan rata-rata kualitas layanan yang signifikan antara kualitas interaksi dengan kualitas lingkungan fisik, kualitas interaksi dengan kualitas hasil, dan kualitas lingkungan fisik dengan kualitas hasil dalam coffee shop asing.

2. Terdapat perbedaan kualitas layanan yang signifikan antara kualitas interaksi dengan kualitas lingkungan fisik, kualitas interaksi dengan kualitas hasil, dan kualitas lingkungan fisik dengan kualitas hasil dalam coffee shop lokal.

3. Terdapat perbedaan kualitas layanan yang signifikan antara coffee shop asing dan lokal.

\section{METODE PENELITIAN}

\section{Gambaran Populasi}

Populasi penelitian ini adalah seluruh pelanggan coffee shop asing dan coffee shop lokal yang ada di Tunjungan Plaza, berusia 15 tahun ke atas dengan minimal pernah mengunjungi coffee shop 1 kali. 


\section{Teknik dan Prosedur Penarikan Sampel}

Jumlah sampel dipilih menggunakan rumus yang dikemukakan oleh Hair et al., (2003, p.345), yaitu:

$$
\mathrm{n}=\mathrm{Z}^{2} \text { B, CL }\left(\frac{(P \times Q)}{\mathrm{e}^{2}}\right)
$$

Dengan mengambil $\alpha=10 \%$ dan tingkat kesalahan pengambilan sampel $\mathrm{e}=5 \%$, dan probabilitas $\mathrm{P}=50 \%$ karena jumlah pelanggan yang tidak diketahui, maka besar sampel yang harus diambil minimum sebesar $\mathrm{n}=272.25$ atau 273 .

Teknik pengambilan sampel yang digunakan adalah quota sampling. Dalam teknik quota ditetapkan beberapa tingkatan kriteria (baik dalam jumlah maupun proporsi) bagi berbagai jenis unsur. Pengambilan sampel sebanyak 300 responden, kemudian dibagi menjadi dua bagian dengan asumsi bahwa jumlah coffee shop asing yang ada di Tunjungan Plaza lebih banyak daripada jumlah coffee shop lokal yaitu 3 coffee shop asing dan 2 coffee shop lokal, sehingga memudahkan peneliti untuk mendapatkan sampel. Dua bagian tersebut yaitu:

1. $60 \%$ untuk responden yang pernah berkunjung di coffee shop asing yaitu 180 responden.

2. $40 \%$ untuk responden yang pernah berkunjung di coffee shop lokal yaitu 120 responden.

\section{Prosedur Pengumpulan Data}

Data penelitian diperoleh dengan menggunakan kuesioner. Kuesioner dibagikan kepada 300 responden yang kemudian dipecah-pecah menjadi dua bagian yaitu: 180 responden dari pengunjung yang pernah berkunjung di coffee shop asing (60 kuesioner akan dibagikan kepada responden yang pernah berkunjung di Starbucks Coffee, 60 kuesioner kepada responden yang pernah berkunjung di Dome Café, 60 kuesioner kepada responden yang pernah berkunjung di Coffee Bean and Tea Leaf) dan 120 responden dari pengunjung yang pernah berkunjung di coffee shop lokal (60 kuesioner kepada responden yang pernah berkunjung di Kafe Excelso dan 60 kuesioner kepada responden yang pernah berkunjung di Grazia Café).

\section{Definisi Operasional Variabel}

a. Kualitas interaksi (Y1) yaitu hubungan antara pelanggan dengan staf coffee shop.

Indikator empirik:

1. Staf bersikap ramah kepada pelanggan (murah senyum).

2. Kesiagaan staf dalam melayani pelanggan.

3. Kecepatan staf dalam melayani kebutuhan pelanggan.
4. Staf menunjukan perilaku yang baik (sopan \& jujur).

5. Staf jarang melakukan kesalahan dalam pekerjaannya.

6. Kemampuan staf dalam menjawab pertanyaan dengan cepat.

7. Pengetahuan staf mengenai menu dan coffee shop.

b. Kualitas lingkungan fisik (Y2) yaitu kualitas lingkungan di dalam coffee shop sewaktu proses penyampaian layanan terjadi.

Indikator empirik:

1. Suhu ruangan yang ada di coffee shop tidak terlalu panas/terlalu dingin (pas).

2. Tata letak meja dan kursi di coffee shop tidak membatasi ruang gerak pelanggan.

3. Tipe pelanggan coffee shop yang lain tidak menggangu kenyaman pelanggan.

4. Coffee shop mengutamakan kebersihan lingkungan (lantai, furniture).

c. Kualitas hasil (Y3) yaitu kualitas yang didapat setelah penyerahan pelayanan selesai diberikan.

Indikator empirik:

1. Waktu tunggu sesuai dengan kualitas yang diberikan.

2. Sejak menerima pesanan sampai pesanan siap, coffee shop memberikan waktu tunggu yang sesuai dengan harapan pelanggan.

3. Menu di coffee shop sesuai dengan selera pelanggan.

4. Pelanggan mendapatkan pengalaman yang baik ketika meninggalkan coffee shop.

\section{Teknik Analisis Data}

1. Analisis Deskriptif

Dalam penelitian ini statistik deskriptif yang digunakan adalah:

- Distribusi frekuensi (fi)

- $\operatorname{Mean}(\mathrm{X})$

Dilakukannya analisis ini untuk memenuhi tujuan penelitian, yaitu mengetahui persepsi konsumen terhadap kualitas layanan di coffee shop asing dan coffee shop lokal.

2. Analisis Perbedaan

Untuk analisis perbedaan, teknik statistik yang digunakan adalah:

- Uji Beda Dua Rata-Rata dengan Paired sample T-Test untuk menguji hipotesis pertama dan kedua yaitu melihat perbedaan antar variabel yang ada dalam kualitas layanan di coffee shop asing dan lokal.

- Uji Beda Dua Rata-Rata dengan Independent Sample T-Test untuk menguji hipotesis ketiga yaitu melihat perbedaan kualitas layanan antara coffee shop asing dengan coffee shop lokal. 


\section{ANALISIS DAN PEMBAHASAN}

\section{Gambaran Umum Responden}

Dari 180 responden coffee shop asing, sebagian besar merupakan responden laki-laki yaitu sebesar $55 \%$ (99 orang). Berdasarkan kelompok usia, sebagian besar responden berusia 21-30 tahun sebesar $48.89 \%$ ( 88 orang), dan memiliki jenis pekerjaan mahasiswa/pelajar sebesar $34.44 \%$ (62 orang). Frekuensi kedatangan responden coffee shop asing yang paling banyak antara 3-5 kali dalam satu bulan sebesar $43.89 \%$ (79 orang), dan sebanyak 127 responden coffee shop asing $(70.56 \%)$ pernah berkunjung ke coffee shop lain.

Sedangkan dari 120 responden coffee shop lokal sebagian besar merupakan responden laki-laki yaitu sebesar 53.33\% (64 orang). Berdasarkan kelompok usia, sebagian besar responden berusia 21-30 tahun sebesar $44.17 \%$ (53 orang), dan memiliki jenis pekerjaan mahasiswa/pelajar sebesar $33.33 \%$ (40 orang). Frekuensi kedatangan responden coffee shop asing yang paling banyak antara $<3$ kali dalam satu bulan sebesar $51.67 \%$ (62 orang), dan sebanyak 81 responden coffee shop lokal $(67.50 \%)$ pernah berkunjung ke coffee shop lain.

Coffee shop lain yang paling banyak dikunjungi oleh responden yang pernah berkunjung di Starbucks dan Grazia Café adalah Kafe Excelso. Sedangkan coffee shop lain yang paling banyak dikunjungi oleh responden yang pernah berkunjung di The Coffee Bean, Dome, Kafe Excelso adalah Starbucks.

\section{Analisis Persepsi Pelanggan Terhadap Kualitas Layanan Coffee shop}

Variabel-variabel yang diteliti adalah (1) kualitas interaksi: (2) kualitas lingkungan fisik: (3) kualitas hasil. Selanjutnya hasil jawaban responden terhadap kualitas layanan akan dianalisis dan dibahas untuk masing-masing variabel.

Tabel 1. Persepsi Pelanggan Terhadap Kualitas Interaksi Coffee shop

\begin{tabular}{lcc}
\hline \multirow{2}{*}{ Indikator } & \multicolumn{2}{c}{ Mean } \\
\cline { 2 - 3 } & $\begin{array}{c}\text { Coffee shop } \\
\text { Asing }\end{array}$ & $\begin{array}{c}\text { Coffee } \\
\text { shop Lokal }\end{array}$ \\
\hline Staf yang ramah & 3.61 & 3.81 \\
Staf selalu siaga & 3.79 & 3.68 \\
Staf cepat dalam melayani & 3.68 & 3.57 \\
Staf sopan dan jujur & 4.03 & 3.88 \\
Tidak sering melakukan & & \\
kesalahan & 3.87 & 3.58 \\
Mampu menjawab pertanyaan & & \\
dengan cepat & 3.93 & 3.72 \\
Memiliki pengetahuan yang baik & 4.03 & 3.74 \\
\hline Sumber : Data primer, diolah
\end{tabular}

Sumber : Data primer, diolah
Dari Tabel 1. dapat dilihat bahwa pelanggan menilai paling bagus pada kualitas interaksi yaitu staf menunjukkan perilaku yang baik terhadap pelanggan dan memiliki pengetahuan yang baik, hal ini terlihat dari hasil pengolahan data dengan nilai Mean 4.03. Para staf yang bekerja di coffee shop asing memiliki pendidikan minimal D1 dan salah satu syarat untuk menjadi staf di coffee shop asing mereka dituntut untuk memiliki great personality. Selain itu staf di coffee shop asing mereka juga dinilai memiliki pengetahuan yang baik, hal ini karena sebelum bekerja di coffee shop mereka diharapkan memiliki pengalaman di bagian food and beverage.

Sedangkan di coffee shop lokal dapat dilihat bahwa pelanggan menilai paling bagus pada kualitas interaksi yaitu staf coffee shop lokal memiliki perilaku yang baik, hal ini dapat dilihat dari pengolahan data dengan nilai Mean 3.88. Seperti halnya di coffee shop asing, staf di coffee shop lokal juga memiliki pendidikan minimal D1. Mereka juga dituntut untuk mau memberikan pelayanan yang baik.

Tabel 2. Persepsi Pelanggan Terhadap Kualitas Lingkungan Fisik Coffee shop

\begin{tabular}{lcc}
\hline \multirow{1}{*}{\multicolumn{1}{c}{ Indikator }} & \multicolumn{2}{c}{ Mean } \\
\cline { 2 - 3 } & $\begin{array}{c}\text { Coffee shop } \\
\text { Asing }\end{array}$ & $\begin{array}{c}\text { Coffee } \\
\text { shop Lokal }\end{array}$ \\
\hline $\begin{array}{l}\text { Suhu ruangan yang sesuai } \\
\text { Tata letak meja kursi tidak }\end{array}$ & 3.91 & 3.77 \\
$\begin{array}{l}\text { membatasi ruang gerak } \\
\text { Pelanggan lain tidak menggangu } \\
\text { kenyamanan }\end{array}$ & 4.19 & 3.35 \\
Lingkungan coffee shop bersih & 3.74 & 3.63 \\
\hline Sumber: Data prim, diolah & & 3.73 \\
\hline
\end{tabular}

Sumber : Data primer, diolah

Tabel 2. menunjukkan bahwa pelanggan coffee shop asing menilai paling bagus pada kualitas lingkungan fisik yaitu tata letak meja dan kursi tidak membatasi ruang gerak pelanggan, hal ini terlihat dari hasil pengolahan data dengan nilai Mean 4.19. Tata letak di coffee shop asing sudah memenuhi syarat kenyamanan menurut Siehoyono dan Ricky dalam buku Food \& Beverage Service Materials (2004, p.44) yaitu jarak minimum antar meja yaitu 2 meter. Selain itu menurut Bapak Joko sebagai outlet manajer di The Coffee Bean And Tea Leaf ingin memberikan kenyamanan bagi pelanggan sehingga mereka bisa merasa seperti di rumah sendiri.

Pelanggan coffee shop lokal menilai paling bagus pada kualitas lingkungan fisik yaitu suhu di coffee shop lokal dirasakan pas (tidak terlalu dingin/terlalu panas) oleh pelanggan dengan nilai Mean 3.77. Hal ini dikarenakan sebagai tamu, mereka mengunjungi 
coffee shop bukan hanya sekitar 5 menit atau 15 menit saja, tetapi bisa lebih dari satu jam. Maka dari itu, pihak coffee shop lokal benar-benar memberikan kenyamanan dengan mengatur suhu ruangan di coffee shop.

Tabel 3. Persepsi Pelanggan Terhadap Kualitas Lingkungan Fisik Coffee shop

\begin{tabular}{lcc}
\hline \multirow{2}{*}{\multicolumn{1}{c}{ Indikator }} & \multicolumn{2}{c}{ Mean } \\
\cline { 2 - 3 } & $\begin{array}{c}\text { Coffee shop } \\
\text { Asing }\end{array}$ & $\begin{array}{c}\text { Coffee shop } \\
\text { Lokal }\end{array}$ \\
\hline Waktu tunggu sesuai kualitas & 3.71 & 3.53 \\
Waktu menunggu pesanan & 3.76 & 3.5 \\
sesuai harapan & 4.07 & 3.92 \\
Menu sesuai selera & 3.56 \\
Ada pengalaman yang baik saat & 3.78 & \\
meninggalkan tempat &
\end{tabular}

Sumber: Data primer, diolah

Dari Tabel 3. dapat dilihat bahwa pelanggan coffee shop asing menilai paling bagus pada kualitas lingkungan fisik yaitu menu yang ada di coffee shop asing sesuai dengan selera pelanggan, hal ini terlihat dari hasil pengolahan data dengan nilai Mean 4.07. Pihak coffee shop asing benar-benar memberikan citarasa terbaik bagi pelanggannya.

Begitu juga menurut pelanggan coffee shop lokal menilai paling bagus pada kualitas hasil yaitu menu yang ada di coffee shop lokal sesuai dengan selera pelanggan dengan nilai Mean 3.77. Hal ini dapat dilihat bahwa coffee shop lokal juga memberikan citarasa yang terbaik bagi pelanggannya.

\section{Uji Hipotesis}

\section{Uji Beda Paired Samples t test}

Uji beda paired sample t-Test di sini untuk melihat apakah ada perbedaan rata-rata yang signifikan di antara kualitas interaksi dengan kualitas lingkungan fisik, kualitas interaksi dengan kualitas hasil, dan kualitas lingkungan fisik dengan kualitas hasil di coffee shop asing dan coffee shop lokal.

Tabel 4. Mean Kualitas Layanan Coffee shop Asing Dan Lokal

\begin{tabular}{lclc}
\hline \multicolumn{2}{c}{ Coffee shop Asing } & \multicolumn{2}{c}{ Coffee shop Lokal } \\
\hline \multicolumn{1}{c}{ Variabel } & Mean & \multicolumn{1}{c}{ Variabel } & Mean \\
\hline Kualitas Interaksi & 3.8492 & Kualitas Interaksi & 3.7095 \\
Kualitas & 3.9542 & Kualitas & Lingkungan Fisik \\
Lingkungan Fisik & & 3.6188 \\
Kualitas Hasil & 3.8278 & Kualitas Hasil & 3.6250 \\
Keseluruhan & 3.8771 & Keseluruhan & 3.6511 \\
\hline
\end{tabular}

Sumber: Data primer, diolah
Dari Tabel 4. dapat diketahui bahwa nilai Mean yang paling tinggi di coffee shop asing adalah kualitas lingkungan fisiknya yaitu sebesar 3.9542 dan yang paling rendah adalah kualitas hasilnya yaitu sebesar 3.8278. Sedangkan untuk di coffee shop lokal nilai Mean yang paling tinggi adalah kualitas interaksinya yaitu sebesar 3.7095 dan yang paling rendah adalah kualitas lingkungan fisiknya yaitu sebesar 3.6188.

Secara keseluruhan diketahui bahwa kualitas layanan baik dari kualitas interaksi, kualitas lingkungan fisik, dan kualitas hasil, di coffee shop asing memiliki nilai Mean yang lebih tinggi. Berarti persepsi pelanggan pada coffee shop asing lebih baik dari coffee shop lokal karena nilai Mean coffee shop asing keseluruhan sebesar 3.8771 lebih tinggi dibandingkan nilai Mean coffee shop lokal yaitu sebesar 3.6511.

Tabel 5. Uji Paired samples T-Test Variabel Kualitas Layanan di Coffee shop Asing

\begin{tabular}{lcccc}
\hline \multicolumn{1}{c}{ Pair } & \multicolumn{2}{c}{ Paired Differences } & \multirow{2}{*}{ S } & \multirow{2}{*}{ Sig. } \\
\cline { 2 - 3 } & Mean & S.D. & & \\
\hline $\begin{array}{l}\text { Kualitas Interaksi- } \\
\text { Kualitas Lingkungan }\end{array}$ & -0.10496 & 0.59440 & -2.369 & 0.019 \\
$\begin{array}{l}\text { Fisik } \\
\text { Kualitas Interaksi- }\end{array}$ & 0.02143 & 0.50393 & 0.571 & 0.569 \\
$\begin{array}{l}\text { Kualitas Hasil } \\
\text { Kualitas Lingkungan } \\
\text { Fisik-Kualitas Hasil }\end{array}$ & 0.12639 & 0.64703 & 2.621 & 0.010 \\
\hline
\end{tabular}

Sumber: Data primer, diolah

Tabel 5 menunjukkan bahwa dari hasil uji beda dengan menggunakan uji t, kualitas interaksi dengan kualitas lingkungan fisik diperoleh $\mathrm{t}_{\text {hitung }}-2.369$ dengan tingkat signifikansi 0.019 karena tingkat signifikansi kurang dari 0.05 (menolak $\mathrm{H}_{0}$ ) maka ada perbedaan rata-rata yang signifikan antara kualitas interaksi dengan kualitas lingkungan fisik di coffee shop asing. Di mana kualitas lingkungan fisik dipersepsikan lebih baik daripada kualitas interaksinya.

Sedangkan antara kualitas interaksi dengan kualitas hasil diperoleh $t_{\text {hitung }} 0.571$ dengan tingkat signifikansi 0.569 . Oleh karena tingkat signifikansi lebih dari 0.05 (menerima H0) maka tidak ada perbedaan yang signifikan antara kualitas interaksi dengan kualitas hasil di coffee shop asing. Jadi kualitas interaksi dipersepsikan hampir sama dengan kualitas hasil di coffee shop asing.

Dan antara kualitas lingkungan fisik dengan kualitas hasil., diperoleh $t_{\text {hitung }} 2.621$ dengan tingkat signifikansi 0.01 . Oleh karena tingkat signifikansi kurang dari 0.05 (menolak $\mathrm{H}_{0}$ ) maka ada perbedaan kualitas lingkungan fisik dengan kualitas hasil di coffee shop asing. Di mana kualitas lingkungan fisik di coffee shop asing dipersepsikan lebih baik daripada kualitas hasilnya. 
Tabel 6. Uji Paired samples T-Test Variabel Kualitas Layanan di Coffee shop Lokal

\begin{tabular}{|c|c|c|c|c|}
\hline \multirow{2}{*}{ Pair } & \multicolumn{2}{|c|}{ Paired Differences } & \multirow{2}{*}{$\mathrm{t}$} & \multirow{2}{*}{ Sig. } \\
\hline & Mean & S.D. & & \\
\hline $\begin{array}{l}\text { Kualitas Interaksi- } \\
\text { Kualitas Lingkungan } \\
\text { Fisik }\end{array}$ & 0.09077 & 0.52888 & 1.880 & 0.063 \\
\hline $\begin{array}{l}\text { Kualitas Interaksi- } \\
\text { Kualitas Hasil }\end{array}$ & 0.08452 & 0.44063 & 2.101 & 0.038 \\
\hline $\begin{array}{l}\text { Kualitas Lingkungan } \\
\text { Fisik-Kualitas Hasil }\end{array}$ & -0.00625 & 0.60152 & -0.114 & 0.910 \\
\hline
\end{tabular}

Tabel 6. menunjukkan bahwa dari hasil uji beda dengan menggunakan uji t, antara kualitas interaksi dengan kualitas lingkungan fisik diperoleh $t_{\text {hitung }}$ 1.880 dengan tingkat signifikansi 0.063 . Oleh karena tingkat signifikansi lebih dari 0.05 (menerima $\mathrm{H}_{0}$ ) maka tidak ada perbedaan kualitas interaksi dengan kualitas lingkungan fisik di coffee shop lokal. Di mana kualitas interaksi coffee shop lokal dipersepsikan hampir sama baiknya dengan kualitas lingkungan fisiknya.

Uji $t$ test antara kualitas interaksi dengan kualitas lingkungan fisik diperoleh $t_{\text {hitung }} 2.101$ dengan tingkat signifikansi 0.038 . Oleh karena tingkat signifikansi kurang dari 0.05 (menerima $\mathrm{H}_{0}$ ) maka ada perbedaan kualitas interaksi dengan kualitas hasil di coffee shop lokal. Di mana kualitas interaksi di coffee shop lokal dipersepsikan lebih baik daripada kualitas hasilnya.

Sedangkan antara kualitas lingkungan fisik dengan kualitas hasil diperoleh nilai $t_{\text {hitung }}-0.114$, dengan tingkat signifikansi 0.910 . Oleh karena tingkat signifikansi lebih dari $0.05\left(\right.$ menerima $\left.\mathrm{H}_{0}\right)$ maka tidak ada perbedaan kualitas lingkungan fisik dengan kualitas hasil di coffee shop local, dimana kualitas lingkungan fisik coffee shop lokal dipersepsikan hampir sama dengan kualitas hasilnya.

\section{Uji Beda Independent Samples t test}

Uji independent t-test untuk melihat apakah ada perbedaan rata-rata yang signifikan dari kualitas interaksi, kualitas lingkungan fisik, dan kualitas hasil antara coffee shop asing dan coffee shop lokal.

Tabel 7. Uji Independent Samples T-Test Kualitas Layanan Antara Coffee shop Asing dengan Coffee shop Lokal

\begin{tabular}{lcccc}
\hline \multicolumn{1}{c}{ Variabel } & $\begin{array}{c}\text { Homoge } \\
\text { nitas }\end{array}$ & $\mathrm{T}$ & Sig. & $\begin{array}{c}\text { Mean } \\
\text { Difference }\end{array}$ \\
\hline Kualitas Interaksi & 0.319 & 2.900 & .004 & 0.13968 \\
Kualitas & 0.614 & 5.648 & .000 & 0.33542 \\
Lingkungan Fisik & 0.649 & 3.494 & .001 & 0.20278 \\
Kualitas Hasil & 0.489 &
\end{tabular}

Sumber: Data primer, diolah
Homogenitas varians kualitas interaksi antara coffee shop asing dan lokal adalah homogen, hal ini terlihat dari nilai signifikansi di kolom uji homogenitas yang nilainya lebih dari 0.05 yaitu dengan nilai 0.319. Dari hasil uji beda dengan menggunakan uji $t$ diperoleh $t$ hitung dengan nilai 2.900, dengan tingkat signifikansi 0.004 . Oleh karena tingkat signifikansi kurang dari 0.05 (menolak $\mathrm{H}_{0}$ ) maka ada perbedaan kualitas interaksi antara coffee shop asing dan coffee shop lokal. Perbedaan ini bisa dilihat dari nilai Mean masing-masing coffee shop. Seperti yang terlihat pada tabel 4. nilai Mean kualitas interaksi di coffee shop asing sebesar 3.8492 sedangkan di coffee shop lokal sebesar 3.7095. Dengan perbedaan ratarata sebesar 0.13968. Dari angka ini terlihat bahwa interaksi staf coffee shop asing dipersepsikan lebih baik daripada staf di coffee shop lokal.

Begitu juga homogenitas varians kualitas lingkungan fisik antara coffee shop asing dan lokal adalah homogen, hal ini terlihat dari nilai signifikansi di kolom uji homogenitas yang nilainya lebih dari 0.05 yaitu dengan nilai 0.614 . Dari hasil uji beda dengan menggunakan uji $t$ diperoleh $t$ hitung dengan nilai 5.648, dengan tingkat signifikansi 0.000 . Oleh karena tingkat signifikansi kurang dari $0.05\left(\right.$ menolak $\left.\mathrm{H}_{0}\right)$ maka ada perbedaan kualitas lingkungan fisik antara coffee shop asing dan coffee shop lokal. Perbedaan ini bisa dilihat dari nilai Mean masing-masing coffee shop. Seperti yang terlihat pada Tabel 4. nilai Mean di coffee shop asing sebesar 3.8492 sedangkan di coffee shop lokal sebesar 3.7095. Dari angka ini terlihat bahwa lingkungan fisik di coffee shop asing dipersepsikan lebih baik daripada di coffee shop lokal.

Uji homogenitas varians kualitas hasil antara coffee shop asing dan lokal adalah homogen, hal ini terlihat dari nilai signifikansi di kolom uji homogenitas yang nilainya lebih dari 0.05 yaitu dengan nilai 0.489. Dari hasil uji beda dengan menggunakan uji $t$ diperoleh $t$ hitung dengan nilai 3.494, dengan tingkat signifikansi 0.001 . Oleh karena tingkat signifikansi kurang dari 0.05 (menolak $\mathrm{H}_{0}$ ) maka ada perbedaan kualitas hasil antara coffee shop asing dan coffee shop lokal. Perbedaan ini bisa dilihat dari nilai Mean masing-masing coffee shop. Seperti yang terlihat pada Tabel 4. nilai Mean di coffee shop asing sebesar 3.8278 sedangkan di coffee shop lokal sebesar 3.6250. Dengan perbedaan rata-rata sebesar 0.20278. Dari angka ini terlihat bahwa kualitas hasil di coffee shop asing dipersepsikan lebih baik daripada di coffee shop lokal. 


\section{KESIMPULAN DAN SARAN}

\section{Kesimpulan}

1. Di coffee shop asing kualitas layanan yang paling bagus adalah kualitas lingkungan fisiknya. Yang kedua adalah kualitas interaksi dan yang ketiga adalah kualitas hasil. Tetapi setelah dilakukan uji beda rata-rata dengan paired sample t-test ternyata ada perbedaan rata-rata yang signifikan antara kualitas interaksi dengan kualitas lingkungan fisik dan antara kualitas lingkungan fisik dengan kualitas hasil. Di mana kualitas lingkungan fisik dipersepsikan lebih bagus daripada kualitas interaksi dan kualitas hasil. Dan tidak ada perbedaan rata-rata yang signifikan antara kualitas interaksi dengan kualitas hasil.

2. Di coffee shop lokal kualitas layanan yang paling bagus adalah kualitas interaksinya, yang kedua adalah kualitas hasil dan yang ketiga adalah kualitas lingkungan fisiknya. Tetapi setelah dilakukan uji beda rata-rata dengan paired sample ttest ternyata ada perbedaan rata-rata yang signifikan antara kualitas interaksi dengan kualitas hasil. Di mana kualitas interaksi dipersepsikan lebih bagus daripada kualitas hasil. Dan tidak ada perbedaan rata-rata yang signifikan antara kualitas interaksi dengan kualitas lingkungan fisik dan antara kualitas lingkungan fisik dengan kualitas hasil.

3. Ada perbedaan kualitas layanan yang signifikan antara coffee shop asing dan coffee shop lokal baik dari kualitas interaksi, kualitas lingkungan fisik, dan kualitas hasil. Dan perbedaan rata-rata terbesar adalah pada kualitas lingkungan fisik. Di mana coffee shop asing memiliki kualitas layanan lebih bagus dibandingkan coffee shop lokal.

\section{Saran}

1. Untuk coffee shop asing

- Meningkatkan kualitas interaksi dengan melakukan training untuk para staf tentang customer satisfaction atau service quality dan membuat standarisasi pelayanan seperti hotel bintang 5 .

- Kualitas lingkungan fisik di coffee shop asing sudah bagus dan harus terus dipertahankan dengan memperbaharui atau memperbaiki fasilitas-fasilitas yang rusak. Ataupun menciptakan atmosfer yang baru setiap tahunnya, sehingga pelanggan tidak merasa bosan.

- Meningkatkan kualitas hasil dengan menetapkan adanya maksimum waktu tunggu untuk pelanggan, misalnya maksimum waktu tunggu adalah 15 menit, bila lebih dari 15 menit maka pelanggan akan mendapatkan bonus.
Maka dari sini para staf akan dipacu untuk bekerja cepat, tetapi tetap harus memperhatikan kualitas yang diberikan.

2. Untuk coffee shop lokal

- Meningkatkan kualitas interaksi dengan memberikan training untuk para staf tentang service quality. Selain itu para manager lebih memperhatikan para stafnya dengan memberikan motivasi supaya mereka dapat bekerja dengan baik dan cepat.

- Meningkatkan kualitas lingkungan fisik dengan mulai mengatur lagi tata letak meja dan kursi sehingga pelanggan dapat bergerak dengan bebas. Dengan mengikuti teori tentang kenyamanan tempat duduk menurut Siehoyono dan Ricky (2004, p.44) yaitu jarak minimum antar meja yaitu 2 meter (jarak meja dengan kursi yaitu sekitar $46 \mathrm{~cm}$ dan jarak antar cabang kurang lebih 1 meter), ketinggian meja kurang lebih $75 \mathrm{~cm}$.

- Meningkatkan kualitas hasil dengan memahami dan mencari tahu apa yang pelanggan inginkan misalnya para manager bertanya secara spontan kepada pelanggan tentang waktu tunggu yang diberikan, tentang selera mereka.

\section{DAFTAR REFERENSI}

Brady, M. K., \& Cronin, J. J. (2001, July). Some new thoughts on conceptualizing perceived service quality: A hierarchical approach. The Journal Of Marketing Vol.65, 34-49.

Grönroos, C. (2000). Service management and marketing: A customer relationship management approach $\left(2^{\text {nd }}\right.$ ed). Chichester: John Wiley \& Sons, Ltd.

Hair, J.F., Bush, R.P., \& Ortinau, D.J. (2003). Marketing research. Boston : Mc Graw-Hill.

Kandampully, J. (2002). Service management: The new paradigm in hospitality. Australia: Hospitality Press..

Kotler, P. (1999). Manajemen pemasaran Jilid 1 (Edisi 6). Jakarta: PT. Prehallindo.

Kotler,P., Bowen, J., \& Makens, J. (1999). Marketing for hospitality and tourism $\left(2^{\text {nd }}\right.$ ed). New Jersey : Prentice-Hall.

Minum kopi bagian gaya hidup. (11 September 2006). Suara Pembaharuan. 12 September 2007.

http://www.suarapembaruan.com/News/2006/

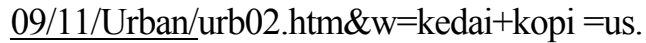


My Blogger. (22 September 2007). Belajar Melihat Potensi Wilayah dengan GIS. 16 Januari 2008.

http:/endahgf.blogspot.com/2007/09/belajarmelihat-potensi-wilayah-dengan.html.

Parasuraman, A., Zeithaml, V.A., \& Berry, L.L. (1985). A conceptual model of service quality and its implications for future research. Journal of marketing Vol.49, 41-50.

Santoso, S. (2003). Mengatasi berbagai masalah statistik dengan SPSS versi 11.5. Jakarta: PT Elex Media Komputindo.

Sarwoko. (2007). Statistik inferensi untuk ekonomi dan bisnis. Yogyakarta : Penerbit Andi.

Siehoyono, L., \& Ricky, M. (2004). Theories of hotel operation and management (tomh): Food and beverage service materials. Hotel Management Program, Faculty of Economics Petra Christian University.
Soekresno. (2000). Manajemen food \& beverage service hotel, Jakarta: PT. Gramedia Pustaka Utama.

Sudarmadi. (26 April-9 Mei 2007). Bisnis dan merek lokal franchiseable. Jakarta : Swasembada 09 Vol. XXIII, 86-87.

Tjptono, F. (2004). Pemasaran jasa. Yogyakarta: Penerbit Andi.

Wikipedia ensiklopedia bebas. (16 Juni 2007). Kota Surabaya. 12 September 2007. http://id.wikipedia.org/wiki/Surabaya.

Zeithaml, V. A., \& Bitner, M. J. (2003). Services marketing integrating customer focus across the firm. New York: McGraw-Hill Companies. 